\title{
Enzymatic determination of ethanol and glycerol by flow injection parallel multi-site detection
}

\author{
António O.S.S. Rangel*, Ildikó V. Tóth \\ Escola Superior de Biotecnologia, Universidade Católica Portuguesa, Rua Dr António Bernardino de Almeida, 4200-072 Porto, Portugal
}

\begin{abstract}
A flow injection method was developed for the sequential enzymatic determination of ethanol and glycerol in wines, using immobilised ethanol dehydrogenase and glycerol dehydrogenase, respectively. The enzymes were immobilised separately on alkylaminated controlled pore glass. A multi-site spectrophotometric detection system was used in parallel configuration to monitor the absorbance change in the two independent analytical channels. A 50-fold dilution of the samples was necessary before injection. The working range was between 0.05 and $0.5 \%(\mathrm{v} / \mathrm{v})$ for the ethanol and between 0.03 and $0.3 \mathrm{gl}^{-1}$ for the glycerol determination, with corresponding detection limits of $2 \times 10^{-3} \%(\mathrm{v} / \mathrm{v})$ and $2 \times 10^{-3} \mathrm{~g} \mathrm{l}^{-1}$. Relative standard deviations (R.S.D.) ( $n=9)$ lower than $2.3 \%$ for the ethanol and $2.1 \%$ for the glycerol determination were found. For 13 samples of different types of table and Port wines, the results showed good agreement with the corresponding reference procedures; a two level recovery study also showed good accuracy for the developed methods. The sampling rate was $10 \mathrm{~h}^{-1}$, corresponding to 20 determinations per hour.
\end{abstract}

Keywords: Sequential flow injection; Ethanol; Glycerol; Multi-site detection; Spectrophotometric enzymatic analysis; Wine

\section{Introduction}

Ethanol is the primary product of yeast fermentation of the grape carbohydrates. The fermentation also leads to different by-products, glycerol being one of the most important. Under normal wine fermentation circumstances the ratio between the concentration of glycerol and ethanol should be approximately 0.07 . Deviations from this value might indicate technological alterations during the process or deterioration of the harvested grape [1].

Ethanol is routinely measured during wine production, using well-established methods that usually in-

\footnotetext{
* Corresponding author. Fax: +351-22-5090351.

E-mail address: rangel@esb.ucp.pt (A.O.S.S. Rangel)
}

volve the separation of the analyte from the sample matrix by distillation before chemical or physical measurements, or then using chromatographic methods [2]. However, glycerol is seldom determined in control laboratories [1]. Although enzymatic assays are now available for both determinations [3], the use of these procedures in routine laboratories is still quite limited, probably due to their high cost. The development of automatic methods of analysis associated with enzyme immobilisation could make the enzymatic assays cost effective, which would emphasise their advantages in terms of sensitivity and selectivity.

Some flow injection (FI) systems with immobilised enzymes have been developed for the determination of the two analytes separately in wines. These systems were either based on spectrophotometric [4,5], 
electrochemical [6-10], chemiluminometric [11-14] or spectrofluorimetric [15] detection methods.

Mattos et al. [16] developed a spectrofluorimetric FI manifold for the sequential determination of glycerol and ethanol using parallel injection and a single detector. This method involved an extensive (1:2500) dilution of the samples before injection.

The objective of the present work was to develop a flow injection system for the sequential determination of ethanol and glycerol using immobilised enzyme reactors and relocatable spectrophotometric detection, with the scope of applying minimum sample pre-treatment. The method was based on the following reactions:

$$
\begin{aligned}
& \text { Glycerol }+\mathrm{NAD}^{+} \stackrel{\text { GlyDH }}{\leftrightarrow} \text { Dihydroxyacetone } \\
& +\mathrm{NADH}+\mathrm{H}^{+} \\
& \text {Ethanol }+\mathrm{NAD}^{+} \stackrel{\mathrm{ADH}}{\leftrightarrow} \text { Acetaldehyde }+\mathrm{NADH}+\mathrm{H}^{+}
\end{aligned}
$$

where GlyDH and ADH indicate glycerol dehydrogenase and alcohol dehydrogenase, respectively. The absorbance change caused by the produced NADH permitted the spectrophotometric quantification of the analytes at $340 \mathrm{~nm}$. Multi-site detection [17] allowed to monitor the absorbance signal in two independent analytical channels using a single detector.

\section{Experimental}

\subsection{Instrumentation}

The FI system consisted of two Gilson Minipuls 2 and 3 peristaltic pumps, an Unicam UV/VIS spectrophotometer equipped with Hellma 178.712-QS flow cell (internal volume: $18 \mu \mathrm{l}$ ), Omnifit PTFE tubing of $0.8 \mathrm{~mm}$ i.d., Omnifit connectors and end-fittings, a diffusion unit [18] with flow channels of $35 \mathrm{~mm} \times 2 \mathrm{~mm} \times 0.5 \mathrm{~mm}$, an injector commutator device [19], T-shaped confluences and a Metrohm E586 Labograph recorder.

\subsection{Reagents and solutions}

Reagents of analytical grade and deionised water were used.
Alcohol dehydrogenase (300-400 $\mathrm{U} \mathrm{mg}^{-1}$, EC1.1. 1.1, ref. 102717) and $\mathrm{NAD}^{+}$(Grade III, 90\%, ref. 710113) were purchased from Boehringer. Glycerol dehydrogenase (65 $\mathrm{U} \mathrm{mg}^{-1}$, EC1.1.1.6, ref. G-3512) and aminopropyl glass (average pore size: $500 \mathrm{~A}$; 200-400 mesh, ref. G-4643) were obtained from Sigma.

For the immobilisation of the enzymes, a $0.1 \mathrm{M}$ phosphate buffer ( $\mathrm{pH} 7.0$ ) and a $2.5 \%$ glutaraldehyde solution in the phosphate buffer were prepared.

For the flow injection system a carbonate buffer solution was prepared by dissolving $10.0 \mathrm{~g}$ of potassium hydrogencarbonate and $10.6 \mathrm{~g}$ anhydrous sodium carbonate in 11 of water and adjusting the $\mathrm{pH}$ to 9.5. The aqueous solution of $8 \mathrm{mM}$ NAD was prepared daily.

Mixed working standard solutions in the concentration range of $0.03-0.3 \mathrm{~g} \mathrm{l}^{-1}$ glycerol and $0.05-0.5 \%$ $(\mathrm{v} / \mathrm{v})$ ethanol were prepared from absolute glycerol and ethanol reagents.

The wine samples were diluted (1:50) in water before introduction to the system.

\subsection{Enzyme immobilisation}

Liophilised glycerol dehydrogenase $(0.4 \mathrm{mg})$ and alcohol dehydrogenase $(1.4 \mathrm{mg})$ were immobilised separately on $0.5 \mathrm{~g}$ of aminopropyl derivatised controlled pore glass following the procedure described by Masoom and Townshend [20] with some modifications [21]; they remained stable for approximately 2 months.

\subsection{Flow injection system}

The developed FI system is presented in Fig. 1A.

In the position shown in the figure, the diluted sample was aspirated through the commutator channel to the gas diffusion unit (GDU) where the ethanol diffused to the acceptor stream $\left(\mathrm{Q}_{1}\right)$ and filled the loop $\mathrm{L}_{2}$. At the same time, the sample $\left(\mathrm{L}_{1}\right)$ introduced into its carrier stream $\left(\mathrm{Q}_{2}\right)$ was mixed with $\mathrm{NAD}^{+}$ $\left(\mathrm{Q}_{3}\right)$ and passed through the enzyme reactor $\left(\mathrm{R}_{2}\right)$ where the conversion of glycerol to dihydroxyacetone occurred. When the produced NADH zone reached the flow cell the absorbance increased continuously towards a maximum value, corresponding to the glycerol content of the sample. The commutator was 
A.

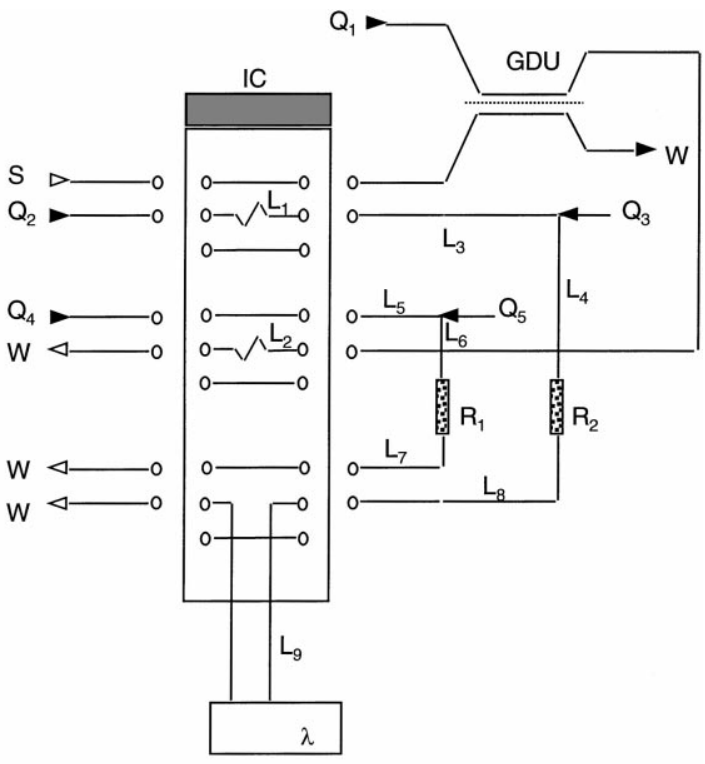

B.

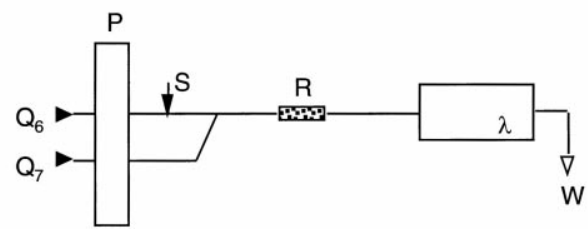

Fig. 1. Manifolds for the sequential determination of ethanol and glycerol in wines by flow injection (FI) analysis (A) and for the preliminary studies (B). IC: injector commutator; $\mathrm{S}\left(1.0 \mathrm{ml} \mathrm{min}^{-1}\right)$ : sample; $\mathrm{Q}_{i}$ : reagent streams; $\mathrm{Q}_{1}\left(1.0 \mathrm{ml} \mathrm{min}^{-1}\right)$ : $0.1 \mathrm{M}$ carbonate buffer $\mathrm{pH} 9.5 ; \mathrm{Q}_{2}\left(0.1 \mathrm{ml} \mathrm{min}^{-1}\right) 0.1 \mathrm{M}$ carbonate buffer $\mathrm{pH} 9.5$; $\mathrm{Q}_{3}\left(0.1 \mathrm{ml} \mathrm{min}^{-1}\right): 8 \mathrm{mM} \mathrm{NAD}^{+} ; \mathrm{Q}_{4}\left(0.3 \mathrm{ml} \mathrm{min}^{-1}\right)$ carbonate buffer $\mathrm{pH}$ 9.5; $\mathrm{Q}_{5}\left(0.3 \mathrm{ml} \mathrm{min}^{-1}\right) 8 \mathrm{mM} \mathrm{NAD}^{+}$; $\mathrm{Q}_{6}$ : carbonate buffer; $\mathrm{Q}_{7}: \mathrm{NAD}^{+}$solution; $\mathrm{L}_{1}$ and $\mathrm{L}_{2}$ injection loops; $\mathrm{L}_{1}: 5 \mu \mathrm{l}$; $\mathrm{L}_{2}: 20 \mu \mathrm{l} ; \mathrm{L}_{3}=\mathrm{L}_{4}=\mathrm{L}_{5}=\mathrm{L}_{6}=10 \mathrm{~cm} ; \mathrm{L}_{7}=\mathrm{L}_{8}=1 \mathrm{~cm} ; \mathrm{L}_{9}=10 \mathrm{~cm} ; \mathrm{R}$ : immobilised enzyme reactor; $\mathrm{R}_{1}$ : alcohol dehydrogenase reactor; $\mathrm{R}_{2}$ : glycerol dehydrogenase reactor; GDU: gas diffusion unit; P: peristaltic pump; $\lambda$ : spectrophotometer, $340 \mathrm{~nm}$; W: waste; indicates the positions where propulsion is applied.

then switched, relocating the detector and injecting the sample in the loop $\mathrm{L}_{2}$ (previously filled by the $\mathrm{Q}_{1}$ stream). After mixing with the $\mathrm{NAD}^{+}$solution $\left(\mathrm{Q}_{5}\right)$, the stream passed through the enzyme reactor $\left(R_{1}\right)$ where the conversion of ethanol to acetaldehyde took place. The absorbance change now recorded corresponded to the ethanol concentration of the sample.

\section{Results and discussion}

\subsection{Study of the flow injection system}

The effect of the different parameters such as injection volumes, flow rates, reagent concentrations and reactor dimensions on the performance of the flow injection system was evaluated. Firstly, each analytical channel was studied separately using a simple manifold (Fig. 1B). The results obtained in the ethanol determination described in a previous work [21] were also considered.

The effect of the injection volume on the sensitivity was studied in the range of 5-50 $\mu$ l. Higher volumes increased sensitivity but also decreased sampling rate. It was found that sample volumes of $15 \mu l$ for the ethanol and $25 \mu \mathrm{l}$ for the glycerol determination yielded satisfactory sensitivity while the sampling rate was still relatively high.

The flow rates also had a large influence on the system performance, since it affected the contact time between the enzymes and the substrates. The flow rate at the enzyme reactors was studied in the range of 0.2 and $1.2 \mathrm{ml} \mathrm{min}^{-1}$. Lower flow rates increased sensitivity and decreased sampling rate. A good sensitivity was obtained for the ethanol at 0.6 and $0.2 \mathrm{ml} \mathrm{min}^{-1}$ for the glycerol determination.

The effect of the $\mathrm{pH}$ of the carbonate buffer on the glycerol determination was studied in the range of $8-10.5$, and maximum sensitivity was obtained at $\mathrm{pH}$ 9.5. Since this value was also applicable for the ethanol determination [21] it was selected as a common buffer solution for the two determinations; this allowed to have approximate baseline absorbance values in both analytical channels.

Experiments with various $\mathrm{NAD}^{+}$cofactor concentrations were carried out in the range of $2-10 \mathrm{mM}$. The sensitivity increased with the concentration until $8 \mathrm{mM}$ and then stabilised, thus this solution was used in the FI manifold.

The influence of the immobilised enzyme reactors length was also studied in the range of $5-30 \mathrm{~mm}$ (i.d. $3 \mathrm{~mm}$ ). Longer reactors increased sensitivity but also increased dispersion of the sample zone, and therefore, decreased sampling rate as well as produced a significant back-pressure. Considering these effects, a length of 25 and $20 \mathrm{~mm}$ was selected for the glycerol and the ethanol determination, respectively. 
After these preliminary studies using the manifold presented in Fig. 1B, application ranges with a good sensitivity were obtained between $10^{-3}$ and $10^{-2} \%$ $(\mathrm{v} / \mathrm{v})$ for ethanol and between $10^{-2}$ and $0.5 \mathrm{~g}^{-1}$ for glycerol determination. Therefore, very different dilutions (1:2500 and 1:30) were necessary to perform the two determinations in the concentration ranges for the wine samples $(2.5-25 \%(\mathrm{v} / \mathrm{v})$ for ethanol and $1.5-15 \mathrm{~g} \mathrm{l}^{-1}$ for glycerol).

As the objective of the work was to develop a system with minimum sample treatment, the first approach was to perform in-line these necessary dilutions. Gas diffusion unit (GDU) has already been proved to be an efficient tool in the ethanol determinations [7,9] for sample dilution and analyte separation. Therefore, the incorporation of a GDU was considered for the ethanol channel, while for the glycerol determination the use of a dialysis unit was tested. However, the passage of glycerol through the dialysis membrane was highly affected by the presence and the concentration of ethanol, therefore, the dialysis process was not applicable under the circumstances for wine analysis. The off-line dilution of the samples was then considered. As this approach does not eliminate the contact of the possible interfering compounds with the enzyme reactor, a minimum injection volume $(5 \mu \mathrm{l})$ must be used. With this volume and 50 times diluted wine samples no interference of the matrix was found. The final configuration of the system was then set as presented in Fig. 1A.

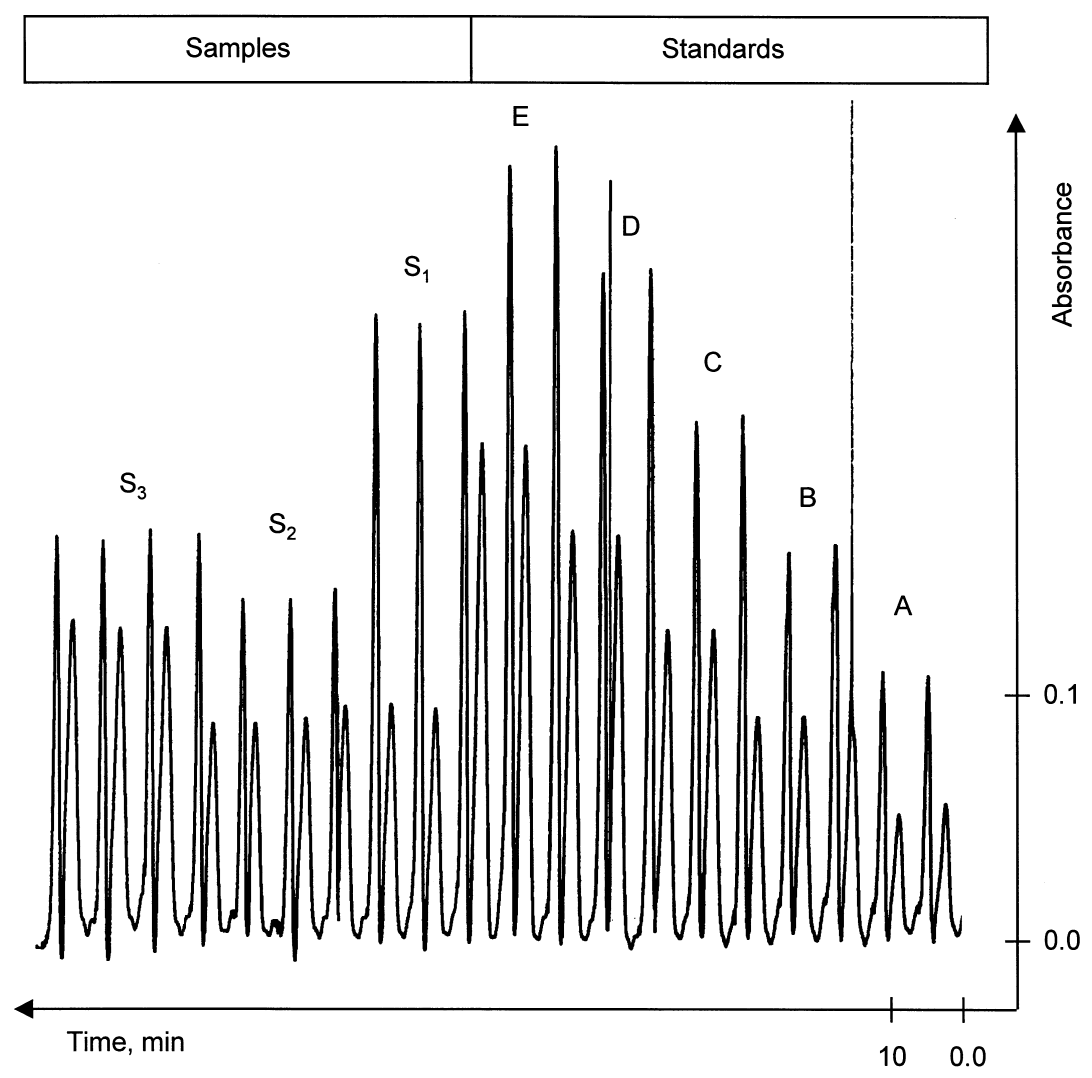

Fig. 2. Recorder output for the sequential determination of ethanol and glycerol content in wines $\left(\mathrm{S}_{i}\right)$. The first peak corresponds to the glycerol and the second to the ethanol determination. The composition of the mixed standards were: A, $0.06 \mathrm{~g} 1^{-1}$ and $0.1 \%(\mathrm{v} / \mathrm{v})$; $\mathrm{B}$, $0.12 \mathrm{gl}^{-1}$ and $0.2 \%(\mathrm{v} / \mathrm{v}) ; \mathrm{C}, 0.18 \mathrm{gl}^{-1}$ and $0.3 \%(\mathrm{v} / \mathrm{v}) ; \mathrm{D}, 0.24 \mathrm{gl}^{-1}$ and $0.4 \%(\mathrm{v} / \mathrm{v}) ; \mathrm{E}, 0.3 \mathrm{gl}^{-1}$ and $0.5 \%(\mathrm{v} / \mathrm{v})$, glycerol and ethanol, respectively. 
The flow rates in the GDU $\left(1 \mathrm{ml} \mathrm{min}^{-1}\right)$ were set to obtain good sensitivity for the ethanol determination.

As in both determinations the absorbing species is the same (NADH), a single spectrophotometer could be used; multi-site detection system was applied to relocate the detector between the two analytical channels. Additionally, as the flow-rate in the glycerol channel is very slow, the relocation of the flow cell to the ethanol channel washes out the remaining tail of the plug and so contributes to increase the sampling-rate.

To reduce the dispersion of the NADH zone and the dead volume of the detector, the connections between the enzyme reactors, the commutator and the flow cell $\left(\mathrm{L}_{7}, \mathrm{~L}_{8}\right.$ and $\mathrm{L}_{9}$ ) were kept to a minimum.

Under the final conditions presented in Fig. 1A, a sampling rate of 10 samples per hour, corresponding to 20 determinations per hour, can be achieved in the desired application range, with calibration curves like absorbance $=0.0536+0.533 \times$ concentration of ethanol and absorbance $=0.0155+0.618 \times$ concentration of glycerol. Detection limits of $2 \times 10^{-3} \%(\mathrm{v} / \mathrm{v})$ and $2 \times 10^{-3} \mathrm{~g} \mathrm{l}^{-1}$ for ethanol and glycerol determinations were found, respectively, calculated as recommended by IUPAC [22].

\subsection{Application to wine analysis}

The FI system was applied to the determination of ethanol and glycerol contents of different Portuguese table and Port wines, both red and white. A recorder output is presented in Fig. 2.

For comparison purposes the different wine samples were analysed by reference methodologies, as well. The ethanol content of the samples was measured after distillation by the hydrometric method [23], while for the determination of glycerol the enzymatic kit of Boehringer [3] was used.

Accuracy of the developed method was evaluated by comparison of the results of the FI method with those of the respective reference determinations. Concentrations and respective relative deviation values for 13 wines are summarised in Table 1.

The results showed relative deviations lower than $2.1 \%$ for the ethanol and lower than $4.0 \%$ for the glycerol determination. A regression line was also used to compare the methods [24]. The resulting equations
Table 1

Results obtained in the analysis of table wine samples by the developed flow injection (FI) method and the reference determinations with the corresponding relative deviation (RD) values

\begin{tabular}{|c|c|c|c|c|c|}
\hline \multicolumn{3}{|c|}{ Ethanol determination } & \multicolumn{3}{|c|}{ Glycerol determination } \\
\hline $\begin{array}{l}\text { FIA }^{a} \\
\%(\mathrm{v} / \mathrm{v})\end{array}$ & $\begin{array}{l}\text { Ref. } \\
\%(\mathrm{v} / \mathrm{v})\end{array}$ & $\begin{array}{l}\mathrm{RD} \\
(\%)\end{array}$ & $\begin{array}{l}\text { FIA }^{a} \\
\left(\mathrm{~g} \mathrm{l}^{-1}\right)\end{array}$ & $\begin{array}{l}\text { Ref. } \\
\left(\mathrm{g}^{-1}\right)\end{array}$ & $\begin{array}{l}\mathrm{RD} \\
(\%)\end{array}$ \\
\hline $11.0 \pm 0.1$ & 11.0 & 0.0 & $6.06 \pm 0.02$ & 6.20 & -2.3 \\
\hline $10.8 \pm 0.1$ & 10.9 & -0.9 & $7.18 \pm 0.0$ & 6.97 & 3.0 \\
\hline $12.2 \pm 0.1$ & 12.2 & 0.0 & $4.33 \pm 0.05$ & 4.26 & 1.6 \\
\hline $11.3 \pm 0.1$ & 11.5 & -1.7 & $6.24 \pm 0.0$ & 6.39 & -2.3 \\
\hline $10.7 \pm 0.3$ & 10.6 & 0.94 & $6.50 \pm 0.05$ & 6.38 & 1.9 \\
\hline $9.70 \pm 0.1$ & 9.50 & 2.1 & $5.07 \pm 0.0$ & 5.00 & 1.4 \\
\hline $19.1 \pm 0.1$ & 19.1 & 0.0 & $2.29 \pm 0.01$ & 2.38 & -4.0 \\
\hline $19.3 \pm 0.1$ & 19.4 & 0.52 & $3.12 \pm 0.15$ & 3.25 & -3.9 \\
\hline $19.7 \pm 0.05$ & 19.6 & 0.51 & $4.72 \pm 0.07$ & 4.81 & -1.9 \\
\hline $20.1 \pm 0.05$ & 19.9 & 1.0 & $4.88 \pm 0.09$ & 4.99 & -2.2 \\
\hline $20.1 \pm 0.3$ & 20.1 & 0.0 & $4.42 \pm 0.09$ & 4.47 & -1.1 \\
\hline
\end{tabular}

a Average of three determinations and the corresponding standard deviations.

were as follows:

For ethanol,

$$
\begin{aligned}
C_{\mathrm{FIA}} & =-0.175( \pm 0.304)+1.014( \pm 0.018) C_{\mathrm{BATCH}} ; \\
R & =0.9997
\end{aligned}
$$

For glycerol,

$$
\begin{aligned}
C_{\mathrm{FIA}} & =-0.135( \pm 0.718)+1.029( \pm 0.116) C_{\mathrm{BATCH}} \\
R & =0.992
\end{aligned}
$$

where $C_{\text {FIA }}$ are the results obtained by the flow injection method and $C_{\mathrm{BATCH}}$ are the results obtained by the reference methods. The values in brackets are the limits of the $95 \%$ confidence intervals. These values indicated no evidence for systematic differences between the sets of results.

A two-level recovery study was also performed with different type of wines, to assess the applicability of the method in a wider concentration range. The first level corresponded to the addition, in the non-diluted samples, of $5 \%(\mathrm{v} / \mathrm{v})$ ethanol and $3 \mathrm{~g} \mathrm{l}^{-1}$ glycerol, and the second level to the addition of $10 \%(\mathrm{v} / \mathrm{v})$ ethanol and $6 \mathrm{~g} \mathrm{l}^{-1}$ glycerol. Recovery values obtained are presented in Table 2.

The precision of the FI method was also tested and relative standard deviation (R.S.D.) values of 2.3, 2.3 and $1.8 \%$ were found for $20.5,8.3$ and $12.0 \%(\mathrm{v} / \mathrm{v})$ ethanol concentrations, respectively. For the determi- 
Table 2

Results obtained in the recovery $(\%)$ study with different types of wines ${ }^{\mathrm{a}}$

\begin{tabular}{|c|c|c|c|c|c|c|}
\hline \multirow[t]{2}{*}{ Wine sample } & \multicolumn{3}{|l|}{ Ethanol determination } & \multicolumn{3}{|c|}{ Glycerol determination } \\
\hline & No addition $\%(\mathrm{v} / \mathrm{v})$ & First addition & $\overline{\text { Second addition }}$ & No addition $\left(\mathrm{g} \mathrm{l}^{-1}\right)$ & First addition & Second addition \\
\hline Table white & 8.7 & 102 & 94.3 & 6.97 & 101 & 103 \\
\hline Table red & 8.3 & 98.4 & 95.2 & 7.65 & 101 & 95.8 \\
\hline Table rose & 8.5 & 103 & 98.7 & 6.53 & 105 & 99.5 \\
\hline Port white & 19.9 & - & - & 4.55 & 102 & 102 \\
\hline Port red & 19.1 & - & - & 5.14 & 105 & 99.2 \\
\hline
\end{tabular}

${ }^{a}$ First level corresponded to the addition of $5 \%(\mathrm{v} / \mathrm{v})$ ethanol and $3 \mathrm{~g}^{-1}$ glycerol addition, in the non-diluted samples, and the second level to the $10 \%(\mathrm{v} / \mathrm{v})$ ethanol and $6 \mathrm{gl}^{-1} \mathrm{glycerol}$, respectively.

nation of the glycerol R.S.D.s of 1.3, 2.1 and $1.4 \%$ were obtained for $4.55,4.47$ and $6.69 \mathrm{~g} \mathrm{l}^{-1}$ concentrations, respectively.

\section{Conclusions}

The features of the proposed methodology make it a good alternative for the simultaneous determination of glycerol and ethanol in wines: the results are comparable to the reference procedures, repeatability is good, and requires minimum sample treatment (dilution).

The manifold configuration developed for this work also emphasises the merits of using multi-site detection to carry out sequential absorbance readings using only one spectrophotometer, thus substantially reducing the cost of the apparatus.

\section{Acknowledgements}

The authors gratefully acknowledge financial support from JNICT through project PBIC/C/BIO/1987/ 95. I.V. Tóth thanks the grant PRAXIS XXI/BD/5643/ 95. Collaboration of Cockburn Smithes (Gaia, Portugal) is also acknowledged.

\section{References}

[1] M.A. Amerine, C.S. Ough, Methods for Analysis of Must and Wines, Wiley, New York, 1980.

[2] Association of Official Analytical Chemists (AOAC), Official Methods of Analysis of AOAC, 16th Edition, AOAC, Gaithersburg, 1997.

[3] Boehringer, Methods of Enzymatic Food Analysis, Boehringer Mannheim GMBH, Mannheim, 1984.
[4] F. Lázaro, M.D. Luque de Castro, M. Valcárcel, Anal. Chem. 59 (1987) 1859.

[5] E.R. Kiranas, M.I. Karayannis, S.M. Tzouwara-Karayanni, Anal. Lett. 30 (1997) 537.

[6] H. Ukeda, Y. Fujita, M. Sawamura, H. Kusunose, Anal. Sci. 10 (1994) 445.

[7] J. Mohns, W. Künnecke, Anal. Chim. Acta 305 (1995) 241.

[8] K. Matsumoto, H. Matsubara, M. Hamada, H. Ukeda, Y. Osajima, J. Biotechnol. 14 (1990) 115.

[9] W. Künnecke, R.D. Schmid, Anal. Chim. Acta 234 (1990) 213.

[10] M.I. Prodromidis, C.D. Stalikas, S.M. Tzouwara-Karayanni, M.I. Karayannis, Talanta 43 (1996) 27.

[11] N. Kiba, N. Azuma, M. Furusawa, Talanta 43 (1996) 1761.

[12] S. Kundruweit, B.A.A. Dremel, R.D. Schmid, Anal. Lett. 27 (1994) 1489

[13] R. Puchades, L. Lemieux, R.E. Simard, J. Food Sci. 56 (1991) 1097.

[14] X. Xie, A.A. Suleiman, G.G. Guilbault, Z. Yang, Z. Sun, Anal. Chim. Acta 266 (1992) 325.

[15] P. Cañizares, M.D. Luque de Castro, Analyst 120 (1995) 2837.

[16] I.L. Mattos, J.M. Fernandez-Romero, M.D. Luque de Castro, M. Valcárcel, Analyst 120 (1995) 179.

[17] E.A.G. Zagatto, H. Bergamin Fo, S.M.B. Brienza, M.A.Z. Arruda, A.R.A. Nogueira, J.L.F.C. Lima, Anal. Chim. Acta 261 (1992) 59.

[18] J.L.F.C. Lima, O.B.A.O. Neves, A.O.S.S. Rangel, in: J.J. Bimbenet, E. Dumoulin, G. Trystram (Eds.), Automatic Control of Food and Biological Processes, Elsevier, Amsterdam, 1994, p. 67.

[19] F.J. Krug, H. Bergamin Fo, E.A.G. Zagatto, Anal. Chim. Acta 179 (1986) 103.

[20] M. Masoom, A. Townshend, Anal. Chim. Acta 166 (1984) 111.

[21] A.O.S.S. Rangel, I.V. Tóth, Am. J. Enol. Vitic. 50 (1999) 259.

[22] IUPAC - International Union of Pure and Applied Chemistry, Anal. Chem. 48 (1976) 2294.

[23] Office International de la Vigne et du Vin (OIV), Recueil des Méthodes Internationales d'Analyse des Vins et des Moûts, OIV, Paris, 1990.

[24] J.C. Miller, J.N. Miller, Statistics for Analytical Chemistry, 3rd Edition, Ellis Horwood, New York, 1993, p. 101. 